\title{
Phenolic content and antioxidant activity of fruit of Brazilian genotypes of feijoa
}

\author{
Cassandro Vidal Talamini do Amarante ${ }^{(1)}$, Alexandra Goede de Souza(1), \\ Thalita Dal Toé Benincá(1) and Cristiano André Steffens ${ }^{(1)}$
}

\begin{abstract}
(1)Universidade do Estado de Santa Catarina, Centro de Ciências Agroveterinárias, Avenida Luiz de Camões, no 2.090, CEP 88520-000 Lages, SC, Brazil. E-mail: cassandro.amarante@udesc.br, alexandra.goede@gmail.com, thalitabeninca@hotmail.com, cristiano.steffens@udesc.br
\end{abstract}

\begin{abstract}
The objective of this work was to quantify the total phenolic content (TPC) and total antioxidant activity (TAA) of fruit from Brazilian genotypes of feijoa (Acca sellowiana). Skin and flesh tissues of the fruit were evaluated for the Alcântara, Helena, Mattos, and Nonante cultivars, and for the 2316 accession. TPC and TAA were both assessed in aqueous and hydroalcoholic extracts, and TAA was assayed by the DPPH (2,2-diphenyl-1-picrylhydrazyl) and ABTS [2,2'-azino-bis(3-ethylbenzothiazoline-6-sulphonic acid)] methods. The TPC values, for aqueous extracts of the skin and flesh tissues, were 114.9 and $88.3 \mathrm{mg}$ gallic acid equivalent (GAE) per $100 \mathrm{~g}$ fresh weight $(\mathrm{FW})$, respectively. The corresponding values for TAA determined by the DPPH method, the skin and flesh tissues, given as $\mathrm{EC}_{50}$ (substrate concentration which leads to $50 \%$ reduction of the DPPH), were 10.7 and $39.7 \mathrm{mg} \mathrm{FW}$ per g DPPH, respectively; and, by the ABTS method, the TAA values were 12.01 and $8.33 \mu \mathrm{mol} \mathrm{L}^{-1}$ Trolox per $\mathrm{g} \mathrm{FW}$, respectively. The greatest values for TPC and TAA were obtained for 'Mattos' and 'Nonante', in the skin, and for 'Nonante' and accession 2316, in the flesh. Feijoa fruit has important functional value, particularly in the skin, characterized by high TPC and TAA.
\end{abstract}

Index terms: Acca sellowiana, Feijoa sellowiana, DPPH and ABTS methods, flesh and skin characterization, functional food.

\section{Compostos fenólicos e atividade antioxidante em frutos de genótipos brasileiros de goiabeira-serrana}

Resumo - O objetivo deste trabalho foi avaliar compostos fenólicos totais (CFT) e atividade antioxidante total (AAT) em frutos de genótipos brasileiros de goiabeira-serrana (Acca sellowiana). As avaliações foram realizadas na casca e na polpa dos frutos, nas cultivares Alcântara, Helena, Mattos e Nonante, e no acesso 2316. CFT e AAT foram determinados em soluções extratoras aquosa e hidroalcoólica, e, para AAT, foram utilizados os métodos DPPH (2,2-difenil-1-picrilhidrazilo) e ABTS [2,2'-azino-bis (3-etilbenzotiazolin) 6-ácido sulfônico]. Os valores de CFT em extrato aquoso na casca e na polpa foram de 114,9 e de 88,3 mg em equivalente de ácido gálico (EAG) por $100 \mathrm{~g}$ de matéria fresca (MF), respectivamente. Para AAT, em extrato aquoso, na casca e na polpa, no método $\mathrm{DPPH}$, os valores de $\mathrm{EC}_{50}$ (concentração de substrato para reduzir em $50 \%$ a concentração inicial de DPPH) foram de 10,7 e $39,7 \mathrm{mg}$ MF por g de DPPH, respectivamente; e, no método ABTS, foram de 12.01 e $8.33 \mu \mathrm{mol} \mathrm{L}^{-1}$ de Trolox por g de MF, respectivamente. Os maiores valores de CFT e AAT foram observados em 'Mattos' e 'Nonante', na casca, e em 'Nonante' e no acesso 2316 na polpa. Os frutos de goiabeira-serrana apresentam importante valor funcional, especialmente no tecido da casca, caracterizado pelos elevados conteúdos de CFT e alta AAT.

Termos para indexação: Acca sellowiana, Feijoa sellowiana, métodos DPPH e ABTS, caracterização de polpa e casca, alimento funcional.

\section{Introduction}

Feijoa or pineapple guava [Acca sellowiana (Berg.) Burret (Syn. Feijoa sellowiana Berg.)] is a flowering plant belonging to the Myrtaceae family, native to the southern region of South America, including the South of Brazil, northern Argentina, and western Uruguay (Pasquariello et al., 2015). Feijoa is not well known in Brazil, but is widely distributed across 
many regions of the world, where it is appreciated for the unique taste and aroma of its fruits. In addition, feijoa has antimicrobial, anti-inflammatory, antitumor, gastroprotective, and hepatoprotective activities (ElShenawi et al., 2008; Weston, 2010; Monforte et al., 2014). However, data on the chemical composition, the phenolic content, and the antioxidant activity of feijoa fruit are scarce, especially in relation to the genotypes cultivated in their places of origin.

In general, fruits are sources of antioxidants, which are important in the human diet. In recent years, greater attention has been given to these fruits since their regular consumption helps to prevent a number of illnesses (Soerjomataram et al., 2010). The antioxidants present in the fruits, especially the phenolic compounds, act as reducing agents toward reactive oxygen species (ROS). ROS are often generated as byproducts of biological reactions or in response to exogenous factors. They can cause disorders at the cellular level on reacting with proteins, lipids, carbohydrates, and nucleic acids. The main types of ROS formed are the superoxide radical $\left(\mathrm{O}_{2}{ }^{-}\right)$, hydrogen peroxide $\left(\mathrm{H}_{2} \mathrm{O}_{2}\right)$, and the hydroxyl radical $\left(\mathrm{OH}^{-}\right)$(Melo et al., 2008). Living organisms have developed ways to neutralize these harmful substances, such as the use of antioxidant agents as a defense. Antioxidant compounds can capture ROS, delaying or hindering the lipid peroxidation process or the oxidation of other molecules; thus, the consumption of foods containing such compounds is important (Carocho \& Ferreira, 2013). However, the disequilibrium between the production of ROS and the presence of antioxidants results in oxidative stress. Premature aging, tumors, and cardiovascular diseases are some of the main effects of the presence of ROS in the human organism (Soerjomataram et al., 2010).

Feijoa is easily cultivated and shows great market potential in relation to the consumption of raw fruit. In the South of Brazil, the fruits are harvested between March and May, depending on the genotype (Santos et al., 2011). The consumption of the skin of the fruit, traditionally seen as an inedible part of feijoa, can provide an important source of nutrients and functional compounds, particularly when included in specific recipes. Therefore, the characterization of the skin is also important.

The objective of this work was to quantify the total phenolic content and total antioxidant activity of fruit from Brazilian genotypes of feijoa.

\section{Materials and Methods}

Feijoa fruits were harvested from the orchard of the germplasm active bank (GAB) of Empresa de Pesquisa Agropecuária e Extensão Rural de Santa Catarina, at the experimental station of São Joaquim $\left(28^{\circ} 16^{\prime} 40^{\prime \prime S}\right.$, longitude $49^{\circ} 56^{\prime} 09^{\prime \prime} \mathrm{W}$, at an altitude of 1,400 m), in 2012, 2013, and 2014. The fruits of four cultivars (Alcântara, Helena, Mattos, and Nonante) and one accession (2316, with the potential to be launched as a cultivar) were collected at the commercial maturity of each genotype, i.e., when the fruits can be easily detached from the trees (Santos et al., 2011). Fruits of 'Alcântara' were harvested in the second fortnight of March, of 'Mattos' in the first fortnight of April, of 'Helena' and the 2316 accession in the second fortnight of April, and of 'Nonante' in the first fortnight of May. After harvest, fruits were immediately transported to the laboratory of postharvest physiology and technology at Universidade do Estado de Santa Catarina (Udesc), where the analysis was carried out.

Total phenolic content (TPC) and total antioxidant activity (TAA) were determined in hydroalcoholic and aqueous extracts of the skin (external epidermis + hypodermis layer + external parenchyma, derived from the hypanthium) and of the flesh (internal epidermis + internal parenchyma + ovarian locule + fleshy tegument + placental bundle + seeds, originated from the development of the ovary) tissues. On the same day the fruits were harvested, the tissues were processed in a multiprocessor, frozen in liquid nitrogen, and stored at $-30^{\circ} \mathrm{C}$. Thus, the fruits belonging to all genotypes (harvested at different times due to differences in their commercial maturity) could be analyzed together for each year of the study.

The procedure for obtaining the extract for TPC and TAA quantification was that adapted by Larrauri et al. (1997). For the hydroalcoholic extraction, $10 \mathrm{~g}$ of the processed tissue were left in a solution of 50\% methanol for 1 hour. The material was then centrifuged at 5,000 rpm for $30 \mathrm{~min}$. The supernatant was stored and the residue subjected to a new extraction with $70 \%$ acetone. After an hour, the material was again centrifuged, the supernatant resulting from the previous step was added, and the volume was made up to $100 \mathrm{~mL}$ with double-distilled water. For the aqueous extraction, the same procedure was used, replacing the hydroalcoholic solutions with double-distilled water. 
The extracts obtained were immediately subjected to TPC and TAA analyses.

TPC quantification was carried out by the FolinCiocalteu colorimetric method, which involves the reduction of the reagent by the phenolic compounds in the sample with the formation of a blue complex with high absorbance at the wavelength $(\lambda)$ of $760 \mathrm{~nm}$ (Swain $\&$ Hillis, 1959). Gallic acid was used as the standard for the phenolic compounds. An aliquot of $2.5 \mathrm{~mL}$ of the extract was removed and $7.5 \mathrm{~mL}$ of double-distilled water were added. In the dark, $1 \mathrm{~mL}$ of the diluted extract was removed and $1 \mathrm{~mL}$ of Folin-Ciocalteu's reagent, $2 \mathrm{~mL}$ of $20 \%$ sodium carbonate and $2 \mathrm{~mL}$ of double distilled water were added. Readings were carried out after $30 \mathrm{~min}$ by spectrophotometry $(\lambda=760$ $\mathrm{nm})$ in triplicate. The TPC of the feijoa fruits was expressed in gallic acid equivalent (GAE) - mg GAE per $100 \mathrm{~g}$ fresh weight $(\mathrm{FW})-$, using the equation of the line for the calibration curve obtained with gallic acid.

TAA was determined using the methodologies based on the capacity of the extract to sequester the 1,1-diphenyl2-picrylhydrazyl radical (DPPH method) according to Brand-Willians et al., 1995, adapted by Milardovíć et al. (2006); and 2,2'-azino-bis (3-ethylbenzothiazoline6-sulphonic acid) radical (ABTS method), as described by Re et al. (1999).

In the DPPH method, five different dilutions of the extracts were prepared in triplicate. In the dark, 0.1 $\mathrm{mL}$ of each extract dilution was used with $3.9 \mathrm{~mL}$ of the DPPH radical. The mixture was stirred in a Vortex mixer and then left to rest. The readings were carried out on a spectrophotometer $(\lambda=515 \mathrm{~nm})$ after $30 \mathrm{~min}$. The minimum antioxidant concentration required to reduce the initial concentration of DPPH by $50 \%\left(\mathrm{EC}_{50}\right.$; mg FW per $\mathrm{g}$ DPPH) was obtained using the equation of the line of the different extract concentrations.

In the ABTS method, the radical was generated from the reaction of the ABTS stock solution $\left(7 \mathrm{mmol} \mathrm{L}^{-1}\right)$ with potassium persulfate $\left(140 \mathrm{mmol} \mathrm{L}^{-1}\right)$, kept in the dark for 16 hours at ambient temperature. Before the analysis, the mixture was diluted in ethylic alcohol until obtaining an absorbance of $0.70 \pm 0.05$ at $\lambda=734$ $\mathrm{nm}$. Employing the extracts obtained from the fruits, five different dilutions were prepared in triplicate. In the dark, $30 \mu \mathrm{L}$ of each dilution of the sample were added to $3 \mathrm{~mL}$ of the ABTS radical, followed by homogenization in a Vortex mixer. The readings were carried out by spectrometry, at $\lambda=734 \mathrm{~nm}$, after $6 \mathrm{~min}$ of mixing. Based on the absorbance values determined from the different extract dilutions, the equation of the line was obtained and the results were expressed as Trolox equivalents ( $\mu \mathrm{mol} \mathrm{L}{ }^{-1}$ Trolox per g FW).

The statistical design was completely randomized with five treatments (corresponding to the five feijoa genotypes) and ten replicates; each replicate comprised five fruits. Since the data obtained for all variables were consistent during the three-year period, only the average values for the three harvests were subjected to the analysis of variance with the SAS software (SAS Institute Inc., Cary, NC, USA), and the averages of treatments were compared by Tukey's test, at $5 \%$ probability.

\section{Results and Discussion}

For all five feijoa genotypes, the TPC was higher in the skin, corresponding to 59.0 and $56.5 \%$ of the total content of the fruit (skin + flesh) for the hydroalcoholic and aqueous extracts, respectively (Table 1).

The TPC values for the fruit skin and flesh differed according to the genotypes. In the skin, 'Nonante' and 'Mattos' showed the highest TPC values, mainly

Table 1. Total phenolic content in hydroalcoholic and aqueous extracts of skin and flesh of feijoa (Acca sellowiana) fruit from different genotypes ${ }^{(1)}$.

\begin{tabular}{lcc}
\hline Genotype & $\begin{array}{c}\text { Hydroalcoholic extract } \\
---(m g \text { GAE per } 100 \mathrm{~g} \text { fresh weight)--- }\end{array}$ & $\begin{array}{c}\text { Aqueous extract } \\
\text { Skin }\end{array}$ \\
\hline Alcântara & $107.7 \mathrm{~b}$ & $115.0 \mathrm{~b}$ \\
Helena & $102.5 \mathrm{c}$ & $111.2 \mathrm{bc}$ \\
Mattos & $117.5 \mathrm{a}$ & $119.8 \mathrm{a}$ \\
Nonante & $119.1 \mathrm{a}$ & $120.5 \mathrm{a}$ \\
Accession 2316 & $102.8 \mathrm{c}$ & $108.0 \mathrm{c}$ \\
\hline Mean & 109.9 & 114.9 \\
CV (\%) & 7.7 & 5.5 \\
\hline & & $76.1 \mathrm{~d}$ \\
Alcântara & $67.6 \mathrm{e}$ & $89.3 \mathrm{~b}$ \\
Helena & $75.7 \mathrm{c}$ & $84.4 \mathrm{c}$ \\
Mattos & $71.3 \mathrm{~d}$ & $96.2 \mathrm{a}$ \\
Nonante & $86.4 \mathrm{a}$ & $95.5 \mathrm{a}$ \\
Accession 2316 & $80.7 \mathrm{~b}$ & 88.3 \\
\hline Mean & 76.4 & 8.9 \\
CV (\%) & 10.9 & \\
\hline
\end{tabular}

${ }^{(1)}$ Means followed by equal letters, within the columns, do not differ by Tukey's test, at $5 \%$ probability. The means refer to averages from 2012, 2013, and 2014. GAE, gallic acid equivalent. 
in the aqueous extract. Also, in the aqueous extracts, accession 2316 showed the lowest TPC values in the skin. 'Nonante' and accession 2316 had the highest TPC values in the flesh, mainly in the aqueous extract. 'Alcântara' showed the lowest TPC values in the flesh, for both extracts (hydroalcoholic and aqueous).

The TPC values in the hydroalcoholic and aqueous extracts were, respectively, 109.9 and $114.9 \mathrm{mg}$ GAE per $100 \mathrm{~g} \mathrm{FW}$ for the skin, and 76.4 and $88.3 \mathrm{mg}$ GAE per $100 \mathrm{~g} \mathrm{FW}$ for the flesh (Table 1). These values are higher than those reported by Monforte et al. (2014) for whole feijoa fruits and lower than the results found for the flesh by Pasquariello et al. (2015). However, the results obtained for the flesh, although higher, are relatively close to the value obtained by Isobe et al. (2003), i.e., $59 \mathrm{mg}$ GAE per $100 \mathrm{~g} \mathrm{FW}$ in the hydroalcoholic extract.

The TPC values in the flesh of feijoa fruits were higher than $41.98 \mathrm{mg}$ GAE per $100 \mathrm{~g} \mathrm{FW}$ obtained for peach (Prunus persica), $43.51 \mathrm{mg}$ GAE per $100 \mathrm{~g} \mathrm{FW}$ for papaya (Carica papaya), and $31.29 \mathrm{mg}$ GAE per 100 g FW for kiwifruit (Actinidea chinensis) (Sartori et al., 2014), all in the aqueous extracts; however, they were lower than $249.49 \mathrm{mg}$ GAE per $100 \mathrm{~g} \mathrm{FW}$ for guavira (Compomanesia sp.) (Campos et al., 2012) and $288 \mathrm{mg}$ GAE per $100 \mathrm{~g}$ FW for strawberry (Fragaria $\mathrm{x}$ ananassa) (Crecente-Campo et al., 2012).

As observed for the TPC values, the skin showed higher TAA than the flesh for all genotypes, quantified by the DPPH and ABST methods, in both extracts (Table 2). The $\mathrm{EC}_{50}$ values (obtained with the DPPH method) for the skin were 14.6 and $57.5 \%$ higher than those for the flesh, for the hydroalcoholic and aqueous extracts, respectively. However, the TAA values obtained with the ABTS method for the skin were 15.9 and $18.1 \%$ higher than those for the flesh, for the hydroalcoholic and aqueous extracts, respectively. These results are in agreement with those obtained by Isobe et al. (2004), where the TAA was also higher in the skin than in flesh of a feijoa genotype cultivated in Japan.

The TAA in the skin and flesh tissues of the fruit differed according to the genotype (Table 2). In the skin, the highest TAA values (quantified through the DPPH and ABTS methods) were observed for 'Mattos' and ' Nonante' for both extracts. In the flesh, the highest TAA obtained by the DPPH method (the lowest $\mathrm{EC}_{50}$ value) was observed for 'Nonante' for both extracts.
Also, in the flesh, for the hydroalcoholic extract, the highest TAA obtained through the ABTS method was found for 'Helena' and the lowest for 'Mattos', while, in the aqueous extract, there was no difference between the genotypes.

TAA data on feijoa fruits are scarce and this hinders a comparison of the results. In the flesh of feijoa produced in Turkey, Tuncel \& Yilmaz (2015) reported TAA values, quantified through the ABTS method, of 63.4-125.5 $\mu \mathrm{mol} \mathrm{L} \mathrm{L}^{-1}$ Trolox per g dry weight (DW). Applying the DPPH method, they obtained $\mathrm{EC}_{50}$ values of 2.56-1.36 mg DW per g DPPH (depending on the concentration of the hydroalcoholic solution and the extraction time). Pasquariello et al. (2015) verified TAA values quantified through the DPPH method, for extracts of feijoa, harvested in the south of Italy, varying from 1.41-2.82 $\mu \mathrm{mol} \mathrm{L}^{-1}$ Trolox per g FW, depending on the genotype. In a study by Beyhan et al. (2010), the percentage inhibition of the DPPH radical obtained for whole feijoa fruits was $92.96 \%$, indicating high TAA.

The TAA values quantified through the DPPH method for the flesh of feijoa $\left(\mathrm{EC}_{50}\right.$ for hydroalcoholic

Table 2. Antioxidant activity quantified by the DPPH $\left(\mathrm{EC}_{50}{ }^{(1)}\right.$; mg FW per $\left.\mathrm{g} \mathrm{DPPH}\right)$ and ABTS $\left(\mu \mathrm{mol} \mathrm{L}{ }^{-1}\right.$ Trolox per $g$ FW) methods in hydroalcoholic (HA) and aqueous extracts of skin and flesh tissues of the fruit from different genotypes of feijoa (Acca sellowiana $)^{(2)}$.

\begin{tabular}{lccccc}
\hline Genotype & \multicolumn{2}{c}{ DPPH method } & & \multicolumn{2}{c}{ ABTS method } \\
\cline { 2 - 3 } \cline { 5 - 6 } Alcântara & HA & Aqueous & HA & Aqueous \\
Helena & $149.6 \mathrm{~b}$ & $10.5 \mathrm{c}$ & & $9.15 \mathrm{ab}$ & $11.84 \mathrm{~b}$ \\
Mattos & $171.1 \mathrm{ab}$ & $14.5 \mathrm{~b}$ & & $8.44 \mathrm{~b}$ & $11.00 \mathrm{bc}$ \\
Nonante & $125.0 \mathrm{c}$ & $4.7 \mathrm{~d}$ & & $9.73 \mathrm{a}$ & $13.09 \mathrm{a}$ \\
Accession 2316 & $187.7 \mathrm{a}$ & $18.6 \mathrm{a}$ & & $7.74 \mathrm{c}$ & $10.62 \mathrm{c}$ \\
\hline Mean & 150.7 & 10.7 & & 8.99 & 12.01 \\
CV (\%) & 22.2 & 52.7 & & 12.7 & 12.1 \\
\hline & & & Flesh & & \\
Alcântara & $212.1 \mathrm{a}$ & $46.5 \mathrm{a}$ & & $6.41 \mathrm{ab}$ & $7.98 \mathrm{a}$ \\
Helena & $206.3 \mathrm{a}$ & $40.6 \mathrm{~b}$ & & $6.92 \mathrm{a}$ & $8.30 \mathrm{a}$ \\
Mattos & $213.0 \mathrm{a}$ & $44.4 \mathrm{a}$ & $5.94 \mathrm{~b}$ & $8.10 \mathrm{a}$ \\
Nonante & $183.1 \mathrm{~b}$ & $32.8 \mathrm{c}$ & $6.65 \mathrm{ab}$ & $8.64 \mathrm{a}$ \\
Accession 2316 & $198.6 \mathrm{a}$ & $34.5 \mathrm{c}$ & $6.66 \mathrm{ab}$ & $8.58 \mathrm{a}$ \\
\hline Mean & 202.2 & 39.7 & 6.52 & 8.33 \\
CV (\%) & 9.8 & 17.4 & 15.5 & 10.1 \\
\hline
\end{tabular}

${ }^{(1)} \mathrm{EC}_{50}$, the minimum antioxidant concentration required to reduce the initial concentration of DPPH by $50 \%$. ${ }^{(2)}$ Means followed by equal letters, within the columns, do not differ by Tukey's test, at 5\% probability. The means refer to averages from 2012, 2013, and 2014. 
extract) are higher than those of: $15,946.52 \mathrm{mg} \mathrm{FW}$ per g DPPH for "araticu-do-mato" (Rollinia sylvatica), 3,249.77 mg FW per g DPPH for "mandacaru -de-trêsquinas" (Cereus hildmannianus), and 3,847.54 mg FW per gDPPH for "pindo palm" (Butia capitata), all native fruit trees in Brazil (Pereira et al., 2013). However, they are lower than the values of: $0.67 \mathrm{mg} \mathrm{FW}$ per g DPPH for "acerola" (Malpighia emarginata), $0.47 \mathrm{mg} \mathrm{FW}$ per g DPPH for "camu-camu" (Myrciaria dubia), and 3.02 mg FW per g DPPH for "jambolão" (Syzygium cumini), all tropical native fruit trees in Brazil (Rufino et al., 2010). Fruits of peach cultivars also showed higher TAA ( $\mathrm{EC}_{50}$ values in hydroalcoholic extract of 5.25$61.25 \mathrm{mg}$ FW per g DPPH) (Santos et al., 2013) than the flesh of feijoa.

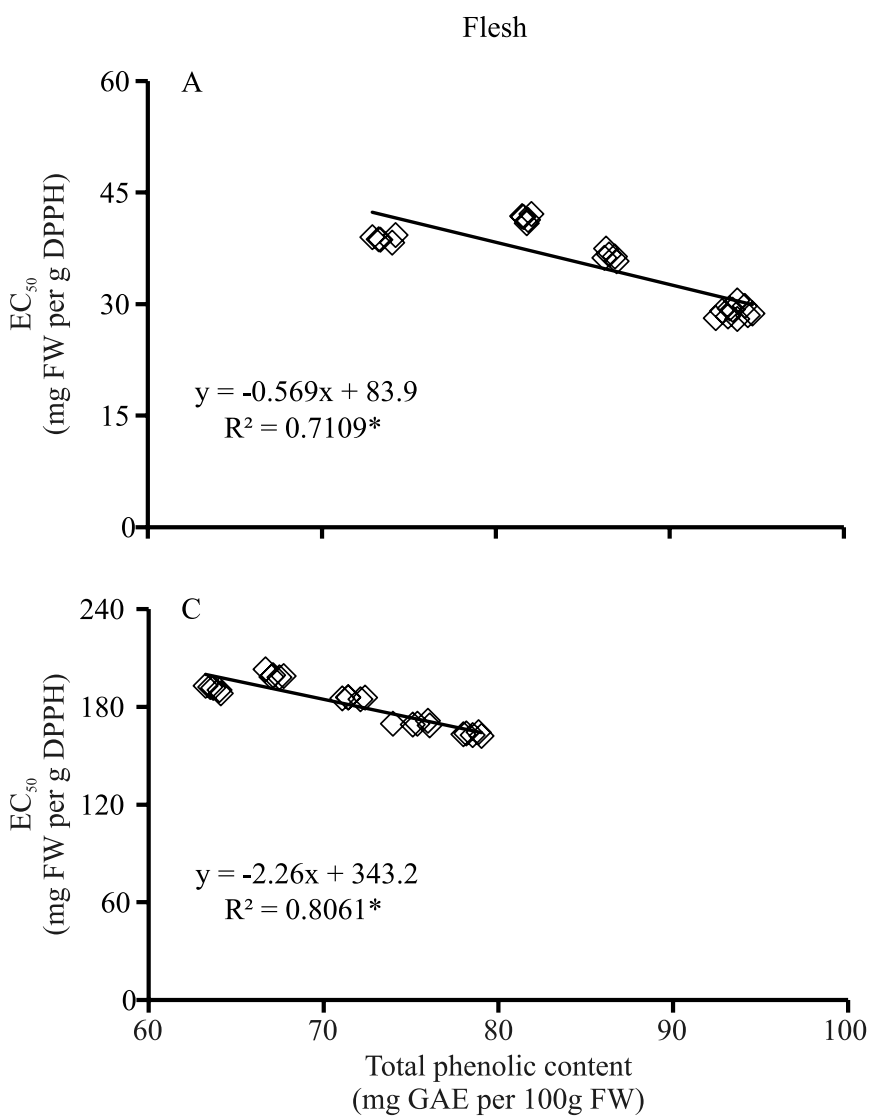

The TAA values quantified through the ABTS method for the flesh of feijoa (in hydroalcoholic and aqueous extracts) are higher than $3.85 \mu \mathrm{mol} \mathrm{L}^{-1}$ Trolox per g FW for "araticu-do-mato", and lower than 11.6 $\mu \mathrm{mol} \mathrm{L}{ }^{-1}$ Trolox per g FW for cashew (Anacardium occidentale), $15.1 \mu \mathrm{mol} \mathrm{L}{ }^{-1}$ Trolox per g FW for "açaí" (Euterpe oleracea), $19.61 \mu \mathrm{mol} \mathrm{L} \mathrm{L}^{-1}$ Trolox per g FW for "mandacaru-de-três-quinas", $25.96 \mu \mathrm{mol} \mathrm{L}^{-1}$ Trolox per g FW for pindo palm, and $37.5 \mu \mathrm{mol} \mathrm{\textrm {L } ^ { - 1 }}$ Trolox per g FW for "jabuticaba" (Myrciaria cauliflora), all native fruit trees in Brazil (Rufino et al., 2010; Pereira et al., 2013).

Regarding the efficiency of the extraction solvent, it was observed that the aqueous extraction resulted in higher TPC and TAA values, for the skin and flesh
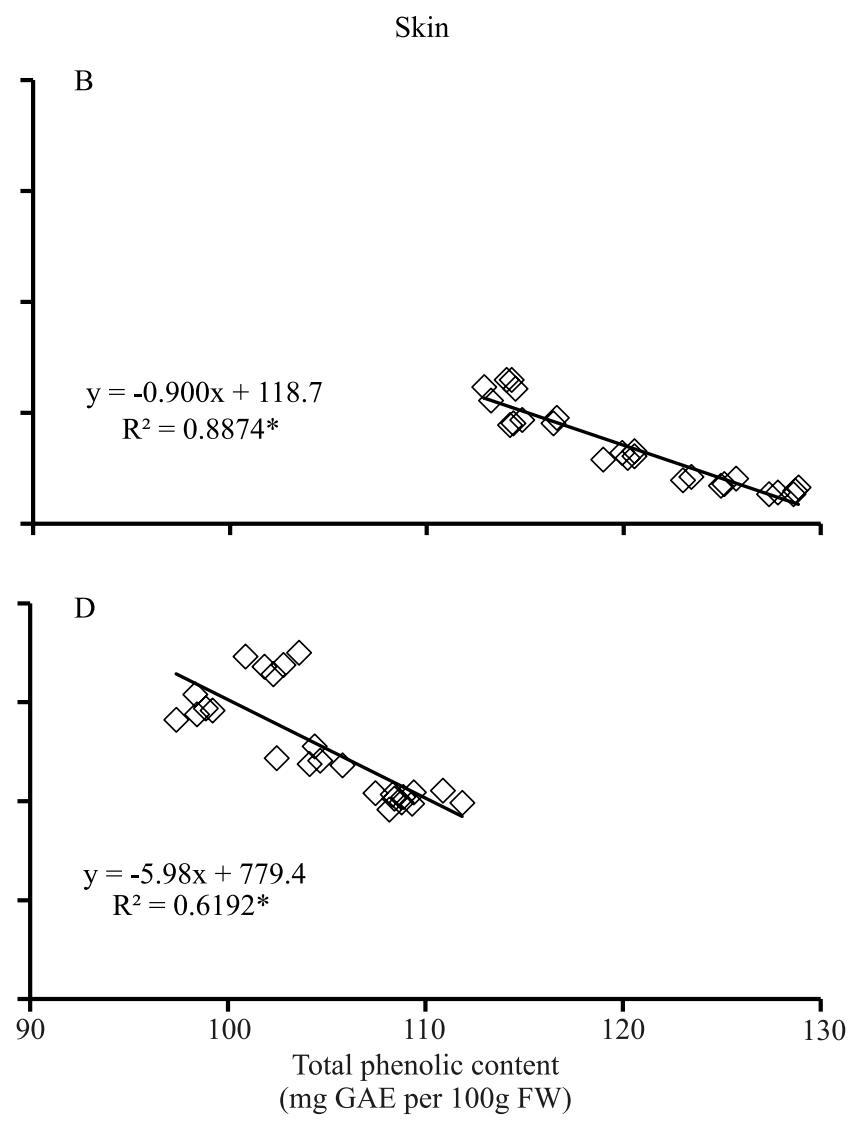

Figure 1. Relationship between total phenolic content and total antioxidant activity quantified by the DPPH method (EC ${ }_{50}$; minimum antioxidant concentration required to reduce the initial concentration of DPPH by $50 \%$.) in aqueous (A and B) and hydroalcoholic (C and D) extracts of flesh and skin tissues, from fruit of five feijoa (Acca sellowiana) genotypes. Values are the mean of three years $(2012,2013$, and 2014). GAE, gallic acid equivalent. FW, fresh weight. *Linear models are significant at $5 \%$ probability. 
tissues of the fruit for all feijoa genotypes, compared with the hydroalcoholic extraction (Tables 1 and 2). This shows that most phenolic compounds, the main antioxidant agents in feijoa fruit, are hydrosoluble. Melo et al. (2008), Vieira et al. (2011), and Rosso (2013) also reported higher TPC and TAA values in the hydrophilic fraction than in the lipophilic fraction of several fruits.

The genetic variability, maturation stage of the fruits, environmental conditions, plant management system and soil fertility, along with the quantification conditions (extraction method), sample size, time and method of sample storage, selection of reagents and presence of interfering substances (such as sugars, waxes, fats, and chlorophyll), all affect TPC quantification (Carbone et al., 2011). These factors can explain the discrepancy between the TPC and the TAA values reported by different authors for feijoa fruits. However, considering that soil and climate conditions, plant management system, and fruit commercial maturity at harvest, in this study, were the same, the differences observed between the genotypes in terms of the TPC and TAA results are probably due to genetic differences.

There was a negative linear correlation between TPC and TAA obtained with the DPPH method (EC50) and a positive linear correlation applying the ABTS method (Figures 1 and 2). This indicates that the phenolic compounds are mainly responsible for the antioxidant activity of feijoa fruits. Overall, the feijoa genotypes
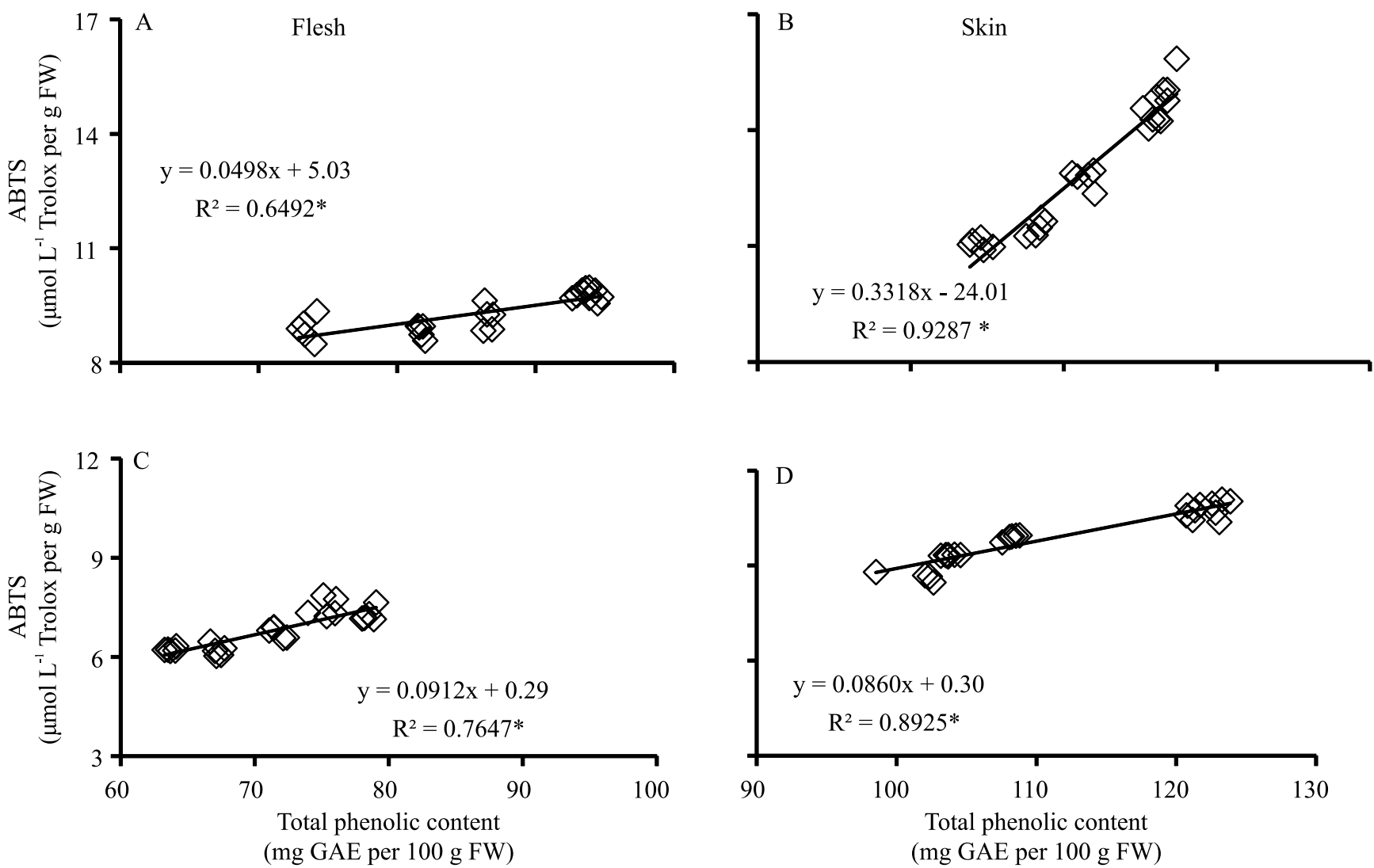

Figure 2. Relationship between total phenolic content and total antioxidant activity quantified by the ABTS method in aqueous (A and B) and hydroalcoholic (C and D) extracts of flesh and skin tissues, from fruit of five feijoa (Acca sellowiana) genotypes. Values are the mean of three years (2012, 2013, and 2014). GAE, gallic acid equivalent. FW, Fresh weight. *Linear models are signifficant at $5 \%$ probability. 
with higher TPC values presented higher TAA for the skin ('Nonante' and 'Mattos') and the flesh ('Nonante' and accession 2316) tissues, and the genotypes with lower TPC values presented lower TAA for the skin ('Helena' and accession 2316) and the flesh ('Alcântara', 'Mattos', and 'Helena') in both extracts.

Phenolic compounds, which are widely distributed in plants, have been receiving considerable attention due to their vast array of biological actions, such as antioxidant activity (Prudêncio et al., 2012; Pereira et al., 2013). Several studies have shown the positive correlation between the TPC and TAA of fruits (Rufino et al., 2010; Oliveira et al., 2011; Rosso, 2013). Higher TPC values for the skin in relation to the flesh have been reported for several fruits (Larrauri et al., 1997; Isobe et al., 2004; Carbone et al., 2011; Ignat et al., 2011), which shows the nutritional contribution of this tissue, commonly discarded during fruit consumption.

Based on this study, the fruits of different genotypes of feijoa cultivated in the South of Brazil can be considered a rich source of antioxidants for human consumption, as well as for the preparation of herbal products to prevent problems related to oxidative cell stress. The fruit skin presents higher TPC and TAA values than the flesh, which highlights the potential for expanding the consumption of this fruit with emphasis on the inclusion of the skin in the diet.

\section{Conclusions}

1. Total phenolic content (TPC) and total antioxidant activity (TAA) are higher in the skin than in the flesh of feijoa (Acca sellowiana) fruits.

2. Total phenolic content and total antioxidant activity in the skin and flesh of feijoa fruits differ according to the genotype.

3. The highest TPC and TAA values in feijoa fruits are observed in the skin of 'Mattos' and 'Nonante', and in the flesh of 'Nonante' and accession 2316.

\section{Acknowledgments}

To Conselho Nacional de Desenvolvimento Científico e Tecnológico (CNPq), for financial support; and to the experimental station of São Joaquim of Empresa de Pesquisa Agropecuária e Extensão Rural de Santa Catarina (Epagri), for supplying the feijoa fruits.

\section{References}

BEYHAN, Ö.; ELMASTAS, M.; GEDIKLI, F. Total phenolic compounds and antioxidant capacity of leaf, dry fruit and fresh fruit of feijoa (Acca sellowiana, Myrtaceae). Journal of Medicinal Plant Research, v.4, p.1065-1072, 2010. DOI: 10.5897/ JMPR10.008.

BRAND-WILLIAMS, W.; CUVELIER, M.E.; BERSET, C. Use of a free radical method to evaluate antioxidant activity. LWTFood Science and Technology, v.28, p.25-30, 1995. DOI: 10.1016/ S0023-6438(95)80008-5.

CAMPOS, R.P.; HIANE, P.A.; RAMOS, M.I.L.; FILHO, M.M.R.; MACEDO, M.L.R. Conservação pós-colheita de guavira (Campomanesia sp.). Revista Brasileira de Fruticultura, v.34, p.41-49, 2012. DOI: 10.1590/S0100-29452012000100008.

CARBONE, K.; GIANNINI, B.; PICCHI, V.; LO SCALZO, R.; CECCHINI, F. Phenolic composition and free radical scavenging activity of different apple varieties in relation to the cultivar, tissue type and storage. Food Chemistry, v.127, p.493-500, 2011. DOI: 10.1016/j.foodchem.2011.01.030.

CAROCHO, M.; FERREIRA, I.C.F.R. A review on antioxidants, prooxidants and related controversy: natural and synthetic compounds, screening and analysis methodologies and future perspectives. Food and Chemical Toxicology, v.51, p.15-25, 2013. DOI: 10.1016/j.fct.2012.09.021.

CRECENTE-CAMPO, J.; NUNES-DAMACENO, M.; ROMERO-RODRÍGUEZ, M.A.; VÁSQUEZ-ODÉRIZ, M.L. Color, anthocyanin pigment, ascorbic acid and total phenolic compound determination in organic versus conventional strawberries (Fragaria x ananassa Duch, cv Selva). Journal of Food Composition and Analysis, v.28, p.23-30, 2012. DOI: 10.1016/j.jfca.2012.07.004.

EL-SHENAWI, S.M.; MARZOUK, M.S.; EL DIB, R.A.; ELYAZED, H.E.A.; SHAFFIE, N.M.; MOHARRAM, F.A. Polyphenols and biological activities of Feijoa sellowiana leaves and twigs. Revista Latinoamericana de Química, v.36, p.103$120,2008$.

IGNAT, I.; VOLF, I.; POPA, V.I. A critical review of methods for characterisation of polyphenolic compounds in fruits and vegetables. Food Chemistry, v.126, p.1821-1835, 2011. DOI: 10.1016/j.foodchem.2010.12.026.

ISOBE, Y.; KASE, Y.; NARITA, M.; KOMIYA, T. Antioxidative activity of the tropical fruit, Feijoa sellowiana Berg. Journal of Home Economics of Japan, v.54, p.945-949, 2003. DOI: 10.11428/ jhej1987.54.945.

ISOBE, Y.; KASE, Y.; NARITA, M.; KOMIYA, T. Antioxidative activity of a polyphenol extract from Feijoa sellowiana Berg and its application to cookies. Journal of Home Economics of Japan, v.55, p.799-804, 2004.

LARRAURI, J.A.; RUPÉREZ, P.; SAURA-CALIXTO, F. Effect of drying temperature on the stability of polyphenols and antioxidant activity of red grape pomace peels. Journal of Agricultural and Food Chemistry, v.45, p.1390-1393, 1997. DOI: $10.1021 /$ jf $960282 \mathrm{f}$.

Pesq. agropec. bras., Brasília, v.52, n.12, p.1223-1230, dez. 2017 DOI: 10.1590/S0100-204X2017001200011 
MELO, E. de A.; MACIEL, M.I.S.; LIMA, V.L.A.G. de; NASCIMENTO, R.J. do. Capacidade antioxidante de frutas. Revista Brasileira de Ciências Farmacêuticas, v.44, p.193-201, 2008. DOI: 10.1590/S1516-93322008000200005.

MILARDOVÍĆ, S.; IVEKOVIC, D.; GRABARIĆ, B.S. A novel amperometric method for antioxidant activity determination using DPPH free radical. Bioelectrochemistry, v.68, p.175-180, 2006. DOI: 10.1016/j.bioelechem.2005.06.005.

MONFORTE, M.T.; LANUZZA, F.; MONDELLO, F.; NACCARI, C.; PERGOLIZZI, S.; GALATI, E.M. Phytochemical compositon and gastroprotective effect of Feijoa sellowiana Berg. fruit from Sicily. Journal of Coastal Life Medicine, v.2, p.14-21, 2014. DOI: 10.12980/JCLM.2.2014J12.

OLIVEIRA, D. da S.; AQUINO, P.P.; RIBEIRO, S.M.R.; PROENÇA, R.P. da C.; PINHEIRO-SANT'ANA, H.M. Vitamina $\mathrm{C}$, carotenoides, fenólicos totais e atividade antioxidante de goiaba, manga e mamão procedentes da Ceasa do Estado de Minas Gerais. Acta Scientiarum. Health Sciences, v.33, p.8998, 2011. DOI: 10.4025/actascihealthsci.v33i1.8052.

PASQUARIELLO, M.S.; MASTROBUONI, F.; DI PATRE, D.; ZAMPELLA, L.; CAPUANO, L.R.; SCORTICHINI, M.; PETRICCIONE, M. Agronomic, nutraceutical and molecular variability of feijoa (Acca sellowiana (O. Berg) Burret) germplasm. Scientia Horticulturae, v.191, p.1-9, 2015. DOI: 10.1016/j.scienta.2015.04.036.

PEREIRA, M.C.; STEFFENS, R.S.; JABLONSKI, A.; HERTZ, P.F.; RIOS, A. de O.; VIZZOTTO, M.; FLÔRES, S.H. Characterization, bioactive compounds and antioxidant potential of three Brazilian fruits. Journal of Food Composition and Analysis, v.29, p.19-24, 2013. DOI: 10.1016/j.jfca.2012.07.013.

PRUDÊNCIO, A.P.A.; PRUDÊNCIO, E.S.; AMBONI, R.D.M.C.; MURAKAMI, A.N.N.; MARASCHIN, M.; PETRUS, J.C.C.; OGLIARI, P.J.; LEITE, R.S. Phenolic composition and antioxidant activity of the aqueous extract of bark from residues from mate tree (Ilex paraguariensis St. Hil.) bark harvesting concentrated by nanofiltration. Food and Bioproducts Processing, v.90, p.399405, 2012. DOI: 10.1016/j.fbp.2011.12.003.

RE, R.; PELlEGRINI, N.; PROTEGGENTE, A.; PANNALA, A.; YANG, M.; RICE-EVANS, C. Antioxidant activity applying an improved ABTS radical cation decolorization assay. Free Radical Biology and Medicine, v.26, p.1231-1237, 1999. DOI: 10.1016/S0891-5849(98)00315-3.
ROSSO, V.V. de. Bioactivities of Brazilian fruits and the antioxidant potential of tropical biomes. Food and Public Health, v.3, p.37-51, 2013. DOI: 10.5923/j.fph.20130301.05.

RUFINO, M. do S.M.; ALVES, R.E.; BRITO, E.S. de; PÉREZJIMÉNEZ, J.; SAURA-CALIXTO, F.; MANCINI-FILHO, J. Bioactive compounds and antioxidant capacities of 18 nontraditional tropical fruits from Brazil. Food Chemistry, v.121, p.996-1002, 2010. DOI: 10.1016/j.foodchem.2010.01.037.

SANTOS, C.M. dos; ABREU, C.M.P. de; FREIRE, J.M., CORREAA, A.D. Atividade antioxidante de frutos de quatro cultivares de pessegueiro. Revista Brasileira de Fruticultura, v.35, p.339-344, 2013. DOI: 10.1590/S0100-29452013000200002.

SANTOS, K.L. dos; DUCROQUET, J.P.H.J.; NAVA, G.; AMARANTE, C.V.T. do; SOUZA, S.N. de; PERONI, N.; GUERRA, M.P.; NODARI, R.O. (Org.). Orientações para o cultivo da goiabeira-serrana (Acca sellowiana). Florianópolis: Epagri, 2011. 44p. (Epagri. Boletim técnico, 153).

SARTORI, G.V.; COSTA, C.V. da; RIBEIRO, A.B. Conteúdo fenólico e atividade antioxidante de polpas de frutas congeladas. Revista Brasileira de Pesquisa em Alimentos, v.5, p.23-29, 2014. DOI: 10.14685/rebrapa.v5i3.143.

SOERJOMATARAM, I.; OOMEN, D.; LEMMENS, V.; OENEMA, A.; BENETOU, V.; TRICHOPOULOU, A.; COEBERGH, J.W.; BARENDREGT, J.; VRIES, E. de. Increased consumption of fruit and vegetables and future cancer incidence in selected European countries. European Journal of Cancer, v.46, p.2563-2580, 2010. DOI: 10.1016/j.ejca.2010.07.026.

SWAIN, T.; HILLIS, W.E. The phenolic constituents of Prunus domestica. I. The quantitative analysis of phenolic constituents. Journal of the Science of Food and Agriculture, v.10, p.63-68, 1959. DOI: $10.1002 /$ jsfa.2740100110.

TUNCEL, N.B.; YILMAZ, N. Optimizing the extraction of phenolics and antioxidants from feijoa (Feijoa sellowiana, Myrtaceae). Journal of Food Science and Technology, v.52, p.141-150, 2015. DOI: 10.1007/s13197-013-0968-0.

VIEIRA, L.M.; SOUSA, M.S.B.; MANCINI-FILHO, J.; LIMA, A. de. Fenólicos totais e capacidade antioxidante in vitro de polpas de frutos tropicais. Revista Brasileira de Fruticultura, v.33, p.888-897, 2011. DOI: 10.1590/S0100-29452011005000099.

WESTON, R.J. Bioactive products from fruit of the feijoa (Feijoa sellowiana, Myrtaceae): a review. Food Chemistry, v.121, p.923926, 2010. DOI: 10.1016/j.foodchem.2010.01.047.

Received on January 4, 2016 and accepted on April 18, 2017 